\title{
Pálosi-Németh Balázs
}

\section{Tökepiacok nyolc új EU-tagországban - látszat- vagy valós fejlettség?}

A tanulmány arra keresi a választ, hogy mi az Európai Unióhoz frissen csatlakozott, volt tervgazdaságú nyolc ország tőkepiacának valós szerepe és lehetősége. A szerző bemutatja, hogy - bár a gazdasági növekedés szempontjából kívánatos a vegyes pénzügyi közvetítés, így a bankrendszer mellett a tökepiac hatékony müködése - a pénzügyi globalizáció hatásai miatt a vizsgált országok tőzsdéinek fejlődése nem lehet párhuzamos az általános intézményrendszer mélyülésével. A tanulmány a szabványosított piacok szerepének kiemelése mellett különböző alapvető stratégiákat is elemez.

Journal of Economic Literature (JEL) kód: F36, G14, G15

Kulcsszavak: feltörekvő tőkepiacok, határon átnyúló kibocsátások, tőzsdei integrációk

\section{Tőzsdei kapitalizáció és FDI}

Érdekes megfigyelni, hogy az 1970-es évektől a fejlődő/feltörekvő piacokra áramló nemzetközi tőke szerkezetében éppen fordított folyamat zajlott le, mint a két világháború között. Míg az 1970-es évek második felében és az 1980-as években a magántőke aránya volt kisebb, és a nemzetközi szervezetek által nyújtott hitelek és segélyek domináltak, addig az 1990-es években megfordult ez az arány, jelenleg mintegy 80\%-ot a magántőke tesz ki. 1982-t megelőzően a magántőke struktúráját tekintve a bankkölcsönök közel 75\%-os arányt képviseltek, ám az 1980-as évek elején zajlott bankválságok után a bankhitelek drasztikusan visszaestek, így az FDI (külföldi közvetlen tőkebefektetések) tudott dominánssá válni. Az 1990-es években az erőre kapó bankhitelek föleg az ázsiai térségre koncentráltak, az FDI is gyorsan nőtt, de mindezeket túlszárnyalva a portfolió-befektetés vált uralkodó formává (Akyüz - Cornford 2002).

Ez utóbbi tény azzal függ össze, hogy a tőkepiacok fejlődésével a feltörekvő országokban is hatékonyabbá válik a piac allokációs mechanizmusa, így a portfolió-befektetések aránya egyre jelentősebb.

Elemzésemet ezért egy „részjelenség” bemutatásával kezdem. A rendszerváltó országokban vizsgálom a közvetlen külföldi befektetések és a tőzsdei kapitalizáció kapcsolatát, mely a fentiek tükrében érdekes indikátora lehet a tőkepiacok fejlettségének. Claessens és

Pálosi-Németh Balázs a Debreceni Egyetem Közgazdaságtudományi Karának Ph.D-hallgatója. E-mail: (balazs.palosi. nemeth@econ.unideb.hu)

Köszönettel tartozom Prof. Dr. Csaba László, Dr. Mohai György és anonim bírálóm értékes megjegyzéseiért. A dolgozatban megfogalmazottak a szerző véleményét tükrözik. Az esetlegesen előforduló bármely tévedés vagy hiba kizárólag a szerző felelőssége. 
szerzőtársai (2002a) nagy mintás - 77 ország adataira és 1975-2000-ig tartó időszakra kiterjedő - vizsgálata azt találta, hogy a külföldi közvetlen tőkebefektetések (FDI) nagysága pozitív kapcsolatban van általában a piaci pénzügyi intézményrendszer mélyülésével, de konkrétan a tőzsdei kapitalizációval és forgalomnövekedéssel is. Azaz, általánosan az FDI kiegészítője és nem helyettesítője egy országba irányuló portfolió-befektetéseknek.

Vizsgálatomat 1995 és 2004 között az új EU-tagállamok közül azokban végzem el, amelyek rendszerváltó országok, azaz Csehország, Észtország, Lengyelország, Lettország, Litvánia, Magyarország, Szlovákia és Szlovénia esetével foglalkozom. Azt találtam, hogy e nyolc országban nem egyértelmü a pozitív kapcsolat a tőzsdei kapitalizáció és a külföldi közvetlen tőkebefektetések között, sőt inkább a helyettesítő hatás dominál.

Ennek bemutatásához először megvizsgáltam a tőzsdei kapitalizáció (1. táblázat), valamint a GDP-arányos külföldi közvetlen tőkebefektetések (2. táblázat) alakulását az egyes országokban.

1. táblázat

Tőzsdei kapitalizáció (milliárd EUR)

\begin{tabular}{|c|c|c|c|c|c|c|c|c|}
\hline 1995 & Csehország & Észtország & Lettország & Litvánia & Magyarország & Lengyelország & Szlovénia & $\frac{\text { Szlovákia }}{4,1}$ \\
\hline 1996 & & & & & & 6,7 & & 4,6 \\
\hline 1997 & & & & & & 10,9 & 1,7 & 4,8 \\
\hline 1998 & & 0,7 & & 0,9 & & 17,6 & 2,3 & 3,5 \\
\hline 1999 & 12,8 & 1,8 & & 3,2 & 16,3 & 29 & 2,8 & 3,6 \\
\hline 2000 & 12,2 & 1,9 & 0,6 & 3,3 & 12,8 & 28,9 & 3 & 3,5 \\
\hline 2001 & 10,6 & 1,7 & 0,8 & 3 & 11,6 & 29,5 & 3,9 & 3,9 \\
\hline 2002 & 15,1 & 2,3 & 0,7 & 2,9 & 8,8 & 27,1 & 5,4 & 2,5 \\
\hline 2003 & 19,9 & 3 & 0,9 & 4,2 & 13,2 & 29,5 & 5,7 & 2,7 \\
\hline 2004 & 32 & 4,4 & 1,1 & 6,1 & 21,1 & 51,7 & 7,1 & 3,6 \\
\hline
\end{tabular}

Forrás: (Eurostat 2005)

2. táblázat

\section{FDI/GDP (\%)}

\begin{tabular}{|c|c|c|c|c|c|c|c|c|}
\hline & Csehország & Észtország & Lettország & Litvánia & Magyarország & Lengyelország & Szlovénia & Szlovákia \\
\hline 1995 & $2,0 \%$ & $2,5 \%$ & $1,4 \%$ & $0,3 \%$ & $5,1 \%$ & $1,3 \%$ & $0,6 \%$ & $0,7 \%$ \\
\hline 1996 & $2,2 \%$ & $3,3 \%$ & $5,0 \%$ & $2,1 \%$ & $4,8 \%$ & $2,9 \%$ & $1,0 \%$ & $1,1 \%$ \\
\hline 1997 & $2,4 \%$ & $1,8 \%$ & $5,2 \%$ & $3,0 \%$ & $5,5 \%$ & $2,6 \%$ & $1,5 \%$ & $0,4 \%$ \\
\hline 1998 & $6,4 \%$ & $9,2 \%$ & $4,7 \%$ & $8,2 \%$ & $3,1 \%$ & $3,8 \%$ & $0,7 \%$ & $1,2 \%$ \\
\hline 1999 & $8,2 \%$ & $7,6 \%$ & $5,3 \%$ & $4,8 \%$ & $5,4 \%$ & $3,8 \%$ & $0,3 \%$ & $3,5 \%$ \\
\hline 2000 & $7,2 \%$ & $4,8 \%$ & $5,5 \%$ & $3,4 \%$ & $0,4 \%$ & $5,3 \%$ & $0,7 \%$ & $9,8 \%$ \\
\hline 2001 & $8,5 \%$ & $6,4 \%$ & $5,9 \%$ & $4,4 \%$ & $1,4 \%$ & $2,8 \%$ & $1,8 \%$ & $7,3 \%$ \\
\hline 2002 & $10,0 \%$ & $4,8 \%$ & $6,1 \%$ & $4,9 \%$ & $1,2 \%$ & $1,7 \%$ & $2,4 \%$ & $16,4 \%$ \\
\hline 2003 & $6,5 \%$ & $4,8 \%$ & $5,9 \%$ & $3,5 \%$ & $1,4 \%$ & $2,1 \%$ & $1,8 \%$ & $5,5 \%$ \\
\hline 2004 & $2,4 \%$ & $6,4 \%$ & $2,4 \%$ & $1,8 \%$ & $2,6 \%$ & $1,3 \%$ & $1,3 \%$ & $1,4 \%$ \\
\hline
\end{tabular}

Forrás: (Eurostat 2005), (UNECE Economic Survey 2005) adatai alapján saját számítás.

A 2. táblázat adatainak felhasználásával két csoportra osztottam a csatlakozó országokat. Az első csoportba az átlagosan alacsony FDI/GDP hányadosokkal rendelkező országok tartoznak (Szlovénia, Magyarország, Lengyelország és Litvánia), a másodikba a magas 
rátával bírók (Csehország, Szlovákia, Észtország, Lettország). Míg az első csoportban a nyilvánosan jegyzett részvénytársaságok számának növekedése 35\%-os volt a vizsgált időszakban, addig a nagyobb FDI/GDP hányadossal rendelkező országokban ez az adat mindössze 17\%. A piaci kapitalizáció az első országcsoportban közel 400\%-kal nőtt, az másodikban csupán 180\%-kal. Ebből tehát arra következtethetünk, hogy ezekben az országokban a közvetlen külföldi tőkebefektetések helyettesítő hatása érvényesül a kiegészítő helyett.

E látszólagos ellentmondásnak - a nagy mintán tapasztaltaktól eltérő jelenségnek - kétféle magyarázata lehetséges. Egyrészt elképzelhető, hogy e nyolc ország piaca már fejlettebb a Claessens és szerzőtársai (2002a) nagy mintájában domináló fejlődő, feltörekvő országokénál, és így a piacok koordinációs szerepének növekedésével a közvetlen külföldi befektetéseket kiszoríthatják a portfolió-befektetések. Másrészt azonban a nagyobb közvetlen tőkebeáramlás megteremti az esélyt a tőkebevonásra a külföldi partner segítségével (az anyavállalaton keresztül). Így a külföldi tulajdonos részesedésének növelésével együtt járhat a hazai szabványosított tőkepiacról való kivezetés is. Azaz, az ok-okozati összefüggés lehet fordított is. E paradox jelenség tehát takarhat csupán egy látszatfejlettséget, amikor átmeneti felfutást követően, a piac fejletlen marad, és az anyavállalatok inkább kivezetik a papírokat a piacról.

A továbbiakban azt mutatom be, hogy általánosabban vizsgálódva az is igaz, hogy a pénzügyi globalizáció hatásai miatt - a szabványosított tőkepiaci intézmények fejlődése nem lehet párhuzamos az általános intézményi mélyüléssel, vagyis nem csupán a közvetlen külföldi befektetések esetében találunk vegyes kapcsolatot a tőzsdei kapitalizációval.

\section{A határokon átnyúló kibocsátások hatása}

A vizsgált nyolc országban a szabványosított tőkepiac létrehozása (újraalapítása) eltérő időben történt meg (1. ábra). Ettől függetlenül ezen országok gazdasági átalakulása sikeresnek tekinthetö, és mindegyikben hasonló szerkezetü pénzügyi közvetítőrendszer jött létre. Így ez összhangban áll azzal - az irodalomban már bizonyított - megállapítással, hogy a gazdasági átalakulás/fejlődés első szakaszában a pénzügyi közvetítés hatása a gazdasági növekedésre jelentéktelen, és a bankok által vezérelt pénzügyi közvetítés dominanciájának kialakulása szükségszerü.

\section{A tőzsdék alapításának időrendje}

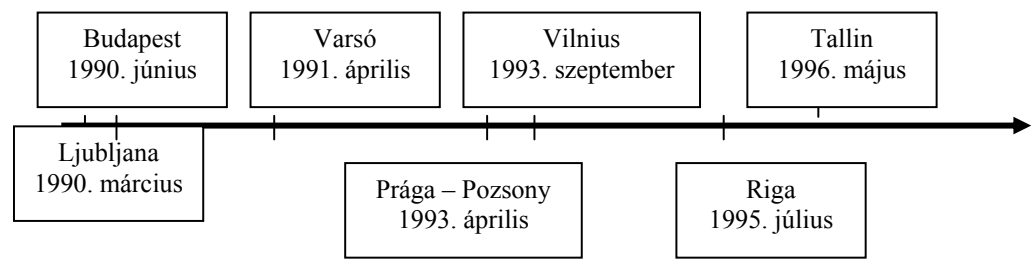

Forrás: saját összeállitás

A tőzsdék alapítását konszolidációs időszak követte, melyben minőségtől függetlenül vezetették be a vállalatokat a parkettre. Ennek következtében néhol (pl. Csehországban és Litvániában) a forgalmazott vállalatok száma több százra, több ezerre nőtt, de általánosan 
igaz volt, hogy a tőzsdei kibocsátást megelőzően a vállalatok piaci alapokra helyezése is hiányzott. A kezdeti jelentős érdeklődést övező pozitív várakozásokat, és a privatizáció egyes formái által elöidézett részvényszám-megsokszorozódást a fokozatos kivezetések időszaka követte, mely időszak alatt az új cégek bevezetésének üteme is elmaradt a korábban tapasztalttól. E tendencia sokkal nyilvánvalóbb volt Csehországban és Litvániában, míg kevésbé látványosan alakult Szlovéniában és Lengyelországban ${ }^{1}$.

E konszolidációs periódus után a tőkeműveletek liberalizációját kihasználó nagyvállalatoknak mint tőzsdei kibocsátóknak a hatása pozitív visszacsatolást jelentett a forgalom és a likviditás növekedésére a helyi tőkepiacokon. Ezt nyilvánvalóan a kisebb, de a minőségi elöírásoknak már megfelelni képes vállalatok piacra lépése is követte. Így a tőzsdei kapitalizáció, mind abszolút mértékben, mind a GDP-hez mérten - országtól függően újra vagy első ízben - jelentősen emelkedett. Ezt a folyamatot természetszerűen erősíthette a javuló makrogazdasági mutatókból és a fejlődő intézményrendszerből adódó befektetöi bizalom növekedése is.

A fentiek következtében elkezdődhetett a feltörekvő tőkepiacok mélyülése, sőt esetenként a fejlettség látszatát keltve komplexitásuk (pl. a derivatív piacok aktivizálódásával²) is kiteljesedett.

Paradox módon azonban éppen a makrogazdasági fundamentumok javulása és a tőkepiacok gyorsnak tűnő fejlődése vezet szükségszerűen a fellendülés végéhez is. $\mathrm{Az}$ 1990-es évek folyamán - köszönhetően az amerikai bull piacok áldásos hatásának, amikor relatíve könnyű volt piacra lépni a tengerentúlon is - a feltörekvő országok nagyvállalatai egyre nagyobb számban ún. határon átnyúló kibocsátásokat hajtottak végre. Ezt alapvetően három módon tehették: duális kibocsátóként (hazai és külföldi piacon történő szimultán megjelenéssel), kizárólag fejlett tőkepiacon történő kibocsátással, illetve letéti igazolások (DR-ek) ${ }^{3}$ segítségével. Claessens - Lee - Zechner (2003a) empirikusan is igazolja azt a tendenciát, hogy az elmúlt 15 évben a pénzügyi központokban nő a nemzetközi papírok aránya. Míg 1989-ben még a fejlődő piacok papírjainak alig néhány százalékával kereskedtek külföldön, mára ez az arány $50 \%$ fölé emelkedett ${ }^{4}$.

A keresztkibocsátások jelensége az Európai Unióhoz 2004-ben csatlakozott országok piacain inkább jellemző, mint Latin Amerikában vagy Ázsiában. Esetenként a piaci kapititalizáció kétharmadát is elérte a külföldön történt bevezetés aránya. Ez a tendencia térségünkben már viszonylag korán megkezdődött. Míg a többi piacon e folyamat csak az 1990-es évek közepén gyorsult fel, addig Európában ez már az 1990-es évek elején megtörtént.

Az európai mércével is jelentősnek számító cégeknél - a globalizáció pozitív hatásaként, a földrajzi korlátok leépülésével - jogosan merült fel a külföldi pénzügyi centrumok „meghódításának” igénye, különösen, ha a hazai tőkepiac fejlődésének üteme nem volt

\footnotetext{
11996 végén Csehországban még 1637 db vállalat részvénye volt a tőzsdére bevezetve. Ez a szám a mélyponton, 2002ben, 64-re esett vissza. Litvániában a csúcspontot az 1997-es év jelentette, amikor 680 vállalat forgott a piacon. Mára ez a szám 50 alá esett (sőt az ún. "fölistás" papírok száma jelenleg mindössze 8). Szlovéniában és Lengyelországban maradt egyedül három számjegyü a forgalmazott részvények száma, bár az ezredfordulót követően ideiglenesen itt is visszaesés következett be.

2 A származtatott termékek piaca Magyarországon 1995-től, Lengyelországban 1998-tól létezik.

${ }^{3}$ Egy bank lejegyzi a papírokat és letéti igazolást (DR - depository receip, GDR - global depository receipt, ADR american depository receipt) bocsát ki. A külföldi ügyfelek ezt vehetik meg, ezzel kereskednek a tözsdén (mint pl. a Magyar Telekommal New Yorkban).

${ }^{4}$ Söt, 1999-ben ez 62\% is volt.
} 
elég gyors ${ }^{5}$, és így a nagyvállalatok forrásbevonási szándéka korlátokba ütközött. Minél inkább valóssá vált a fejlettség az adott piacon - javult a likviditás, a piaci kapitalizáció, kiegyensúlyozottakká váltak az ország makrogazdasági adatai -, annál könnyebb lett egy hazai nagyvállalat számára a külföldi piacra lépés.

Az ilyen „elvándorlások” legfőbb okai, hogy a nemzetközi piacokon való megjelenés alacsonyabb tranzakciós költségekkel, alacsonyabb elszámolási kockázattal, valamint hatékonyabb, a valós kockázatokat tükröző árazással kecsegtet.

Doidge-Karolyi-Stulz (2004) munkája még alaposabb magyarázatot igyekszik találni a határon átnyúló kibocsátások tömegessé válására: 1997 végén az USA-ban kibocsátó külföldi vállalatok Tobin-féle q-mutatója 16,5\%-kal magasabb volt, mint az azonos országból származó, de az USA-ban nem piacra lépő cégeké. A vállalatok értéke szignifikánsan magasabb volt (37\%) az Egyesült Államok valamelyik nagy tőzsdéjének szimultán kibocsátóinál. A különbség a vállalatok számának és az országjellemzők kiszürésével tovább nőtt. Doidge-Karolyi-Stulz (2004) azt is megmutatták, hogy már önmagában egy pénzügyi centrumban történő kibocsátás híre is jelentős értéknövekedést von maga után. Ennek magyarázata lehet egyrészt, hogy az amerikai kibocsátás - mintegy „importálva” a fejlett intézményrendszert - csökkenti a veszélyét annak, hogy az irányító tulajdonos többségi részesedését kihasználva külön hasznot húzzon, egyedi előnyöket szerezzen, elsajátítson. Másrészt növeli a vállalat képességét a növekedési lehetőségek kiaknázására. Következésképpen azon tulajdonosok számára, akik engedik bevezetni vállalataikat egy nagy tőkepiacra, fontosabb a növekedési lehetőségek kihasználása, mint a privát hasznok elsajátítása, azaz hosszú távú szemléletmód jellemzi őket, és ezt jelzik is a piac számára, ezért értéktöbbletet realizálhatnak.

Claessens - Klingebiel - Schmukler (2003b) tanulmányában felfedezhető a párhuzam a fentiekkel. 53 ország piacain végzett nagymintás felmérésük megállapította, hogy a vállalati jellemzők - nagyság, növekedés, érték, teljesítmény és nemzetközi aktivitás - fontos meghatározói a cégértéknek a fejlett tőkepiacokon, de sokkal kevésbé az a fejlődökön. Megmutatták, hogy attól függöen, hogy az adott ország intézményrendszere milyen mértékben alkalmazkodott a nemzetközi standardokhoz, a vállalatok a keresztkibocsátás eszközéhez nyúlnak, mely a hatékonyság érvényesülését segíti. Így a nemzetközivé válás a felelös vállalatirányítás (corporate governance) fontos (helyettesítő vagy kiegészítő) eszközévé vált a hatékonyság megvalósítása, a független vezetés és ellenőrzés területén. A szerzők bizonyították, hogy a külföldi kibocsátás az eladások növekedésével, magasabb megtérüléssel és alacsonyabb tőkeköltséggel jár, és így magasabb részvényesi értékben testesül meg.

A feltörekvő piacon rövid távon a kettős kibocsátásnak áldásos hatásai is lehetnek, ez támpontot biztosít a hazai kereskedés számára, az érdeklődés fokozódásával pedig a likviditás növekedéséhez vezet. Ám éppen azért, mert a fejlődő országok tőzsdéi a nagyvállalatok tőkeallokációjában - sem likviditásban, sem az elérhető potenciális befektetők számában - nem képesek kompetitív előnyre szert tenni, a kereskedés volumene fokozatosan a fejlettebbek felé tolódik el. A fejlődés bizonyos fokán tehát a likviditás nem növekszik tovább, sőt csökkenni kezd. Az ezzel együtt járó csökkenő forgalom miatt a piacok aktivitása és átláthatósága csökken, a kereskedés implicit költségei megnőnek. A tényleges forgalmat biztosító cégek anyavállalatai fokozatosan kivezetik leányvállalataikat a piacról,

\footnotetext{
${ }^{5}$ Vagy tipikusan zsákutcás volt, ahol bizonyos területek fejlesztése elszakadt a realitásoktól.
} 
mert a helyi tőzsde lényegében funkcióját veszti, azaz a nyilvánosság direkt és indirekt költségei meghaladják annak előnyeit. A természetes koncentrálódásából adódóan tovább csökken a közkézhányad, a kisbefektetők érdekei sérülhetnek, s ez az érdeklődést még inkább visszaveti, így a kisebb cégek is elhagyhatják a „parkettet”.

A tőkepiacok mélyülésének tehát van egy felső korlátja, az elvándorlás erősödése mellett, amikor a külföldre irányuló migráció negatív hatásai egyre erősebbé válnak és a hazai likviditás visszaesése következik be.

Az Európai Unión belül a tőkepiacok egységes szabályozási keretének kialakítása tovább nehezíti majd a kis piacok fennmaradását. A Lámfalussy Bizottság által kidolgozott Pénzügyi Szolgáltatási Akcióterv (Financial Sercive Action Plan, FSAP) az egységes európai tőkepiac megteremtését célozva egységes szabályozási környezetet teremt. Ez nem csupán az átláthatóság és a nyilvánosság kritériumainak egységesítése miatt még tovább erősödő verseny miatt okoz további nehézségeket a feltörekvő piacok számára. Ekkor ugyanis lehetővé válik a partnerek számára bármely pénzügyi tranzakció piacának szabad választása, vagyis a jövőben - ha a legjobb teljesítés (best execution) feltételei fennállnak - a koncentrált piacot elkerülve is megköthetők az ügyletek. A versenyt pedig az egységes engedélyezés (single passport) rendszere is növeli, mely vonatkozik majd mind a kibocsátókra, mind a befektetési szolgáltatókra.

Természetesen a fent leírt folyamattal ellentétes hatások is érvényesülnek. Bár a fejlődő-feltörekvő országokban a vállalatok egyre nagyobb számban lennének képesek a duális kibocsátásra, mégis egy részük nem tud külföldön saját tőkét bevonni. Még ha méretükből adódóan meg is felelnének a nyugat-európai vagy tengerentúli szigorú kritériumoknak, legtöbbször az ún. információs hatékonyság az oka annak, hogy a hazai tőkepiac az egyetlen releváns piac. A nagy intézményi befektetők figyelme elsősorban a jelentősebb értékpapír-kibocsátókra összpontosul, ahol a befektetés egységnyi összegére jutó információs költség alacsonyabb. Már a közepes méretü vállalatok is elvesznek egy nagy nemzetközi tőzsde széleskörü kínálatában. Ennek egyik, talán legfőbb oka a következő. A passzív portfoliókezelés egyre fokozódó térnyerése, és a különböző benchmarkhoz kötött, indexkövető termékek elterjedése - melyek nem tartalmazzák a kisebb vállalatok papírjait -nem kedvez bizonyos méret alatti kibocsátóknak. E cégek magasabb költséggel tudnak csak forráshoz jutni, e téren tehát megmaradhat a helyi piacok fontos szerepe a finanszírozásban, hiszen azok felkészültebbek, fontosabb számukra a hazai kibocsátó, mint a globális cégeknek. Davis (1995) mutat rá arra, hogy a világméretü alapok kezelői körében megfigyelhetö „csordaszellem” (herding) is azt igazolja, hogy a nagy intézményi befektetőknek még rövid távon sem szabad eltérniük az átlagtól vagy a teljesítmény mérésére használt benchmarktól, mert egy esetleges rosszabb hozam hamar a vagyonkezelöi mandátum elvesztéséhez vezethet. Ez viszont azt jelenti, hogy számos, elsősorban a feltörekvő piacokon működő vállalat nem kapja meg a teljesítményének megfelelő figyelmet, mely részvényeinek likviditáscsökkenéséhez, alulértékeltséghez vezethet.

Az információs hatékonyság létezésének empirikus bizonyítékát adja Bae-Stulz-Tan (2005) munkája. 32 országra kiterjedő elemzésükben megmutatták, hogy a helyi elemzők teljesítménye a vállalatok fundamentumainak vizsgálatában jelentősen felülmúlta a nemzetközi elemzőkét.

Érdekes megfigyelni az analógiát a mai pénzügyi centrumok és a feltörekvő országok vállalatainak kapcsolata, valamint az amerikai aranylázat követő „tőzsdeszaporulat” között. Egyik oka ugyanis annak, hogy a XIX. században az Egyesült Államok területén 
több száz börze működött, és még ma is több helyi piac létezik az, hogy a legnagyobb piacok - hírnevük és vonzerejük fenntartása érdekében - nem vezetnek be saját parkettjükre áttekinthetetlen mennyiségü és minőségü értékpapírt. Márpedig Csehországban, Lengyelországban és Szlovákiában mindössze a kibocsátó vállalatok 10\%-a éri el az egymilliárd dolláros eszközállományt és az egymilliárd dolláros éves árbevételt. Magyarországon ez az aránytalanság még szembetünőbb (4\%). Hazánkban, Lengyelországban és Szlovákiában a cégek több mint fele még 100 milliós árbevételt sem realizál évente. Összességében ez azt jelenti, hogy a kibocsátók többsége méret tekintetében nem éri el a nyugati tőzsdékre való bevezetés minimumkövetelményét sem.

A pró és kontra érvek ütköztetése után nézzük, mi is a „nettó" hatás?

Levine és Schmukler (2003) tanulmányukban 55 ország 3200 vállalatát vizsgálták 1989 és 2000 között. Eredményeik alátámasztják, hogy a külföldi megjelenés után az adott cég papírjainak kereskedése súlypontot vált a hazairól a fejlettebb piac javára. A nagyvállalatok likviditásának csökkenése miatt a piaci szereplők érdeklődése vagy a teljes hazai piac iránt csökken, vagy éppen a nemzetközi mércével is elfogadott vállalat kap nagyobb figyelmet, torzítva ezzel a csak hazai piacon kereskedett vállalatok likviditását.

Levine és Schmukler (2005) munkája a nemzetközi piacon való megjelenésnek a hazai piacra gyakorolt negatív hatását két komponensre bontja: az elvándorlás (migration) közvetlen hatására, illetve ennek közvetett hatására (spillover) az összpiaci forgalom csökkenésére. Ez utóbbi abból adódik, hogy a piac müködtetésének fix költségeit (a brókercégek működési költségei, az elszámolási és klíring költségek, stb.) a hazai piacon maradó vállalatok forgalmazásának kellene fedeznie, hiszen így nő az egy kereskedésre jutó költségük. Claessens és szerzőtársai (2006) nagy mintán elemzik a különböző országcsoportok vállalatainak migrációs tendenciáit. A 2-4. ábrán látható, hogy éppen a feltörekvő, azaz a közepes jövedelmü országokban a legerősebb a tendencia.

2. ábra

A külföldi tőkepiacon bevont tőke a hazai piacon bevont tőkéhez képest

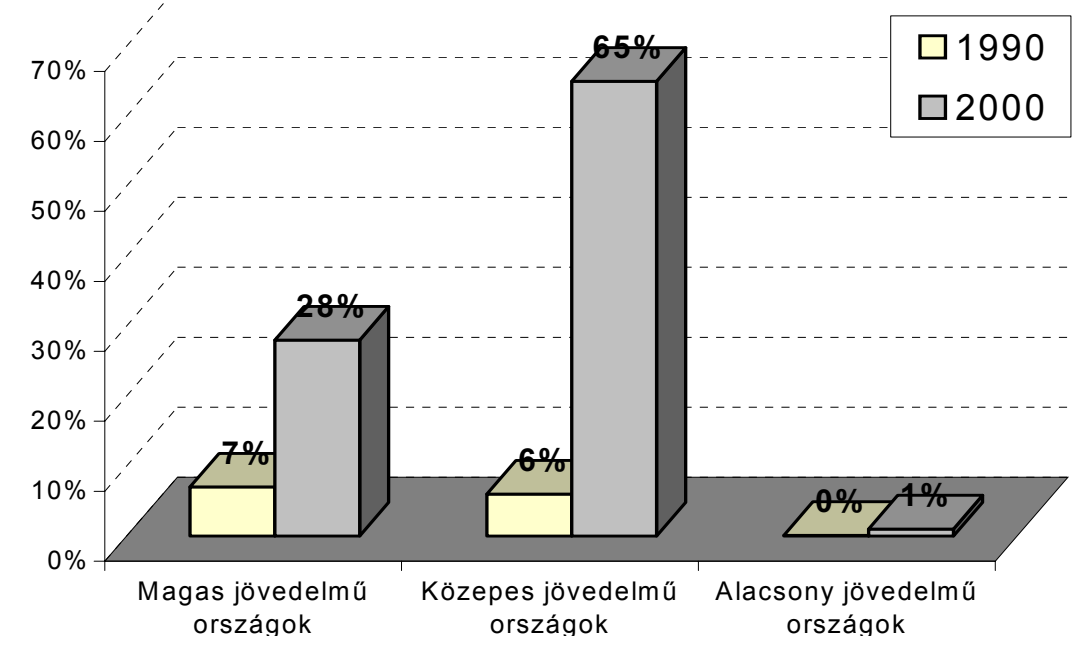

Forrás: (Claessens és társai 2006) 


\section{A külföldön jegyzett vállalatok piaci kapitalizációja} a teljes piaci kapitalizációhoz képest

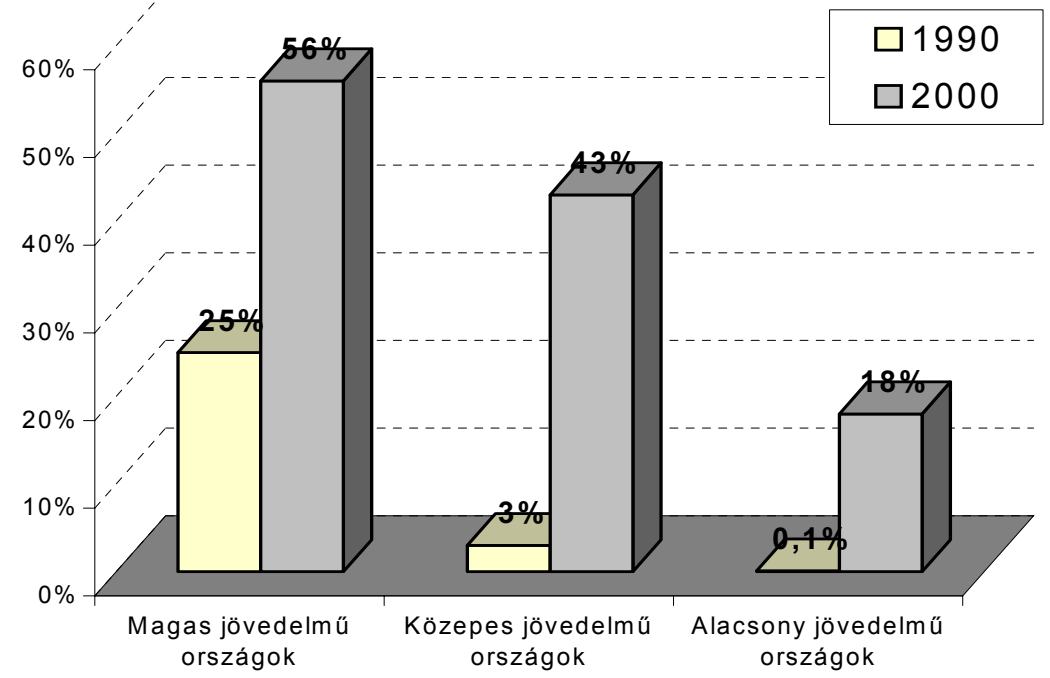

Forrás: (Claessens és társai 2006)

\section{A külföldi forgalom nagysága a hazai százalékában}

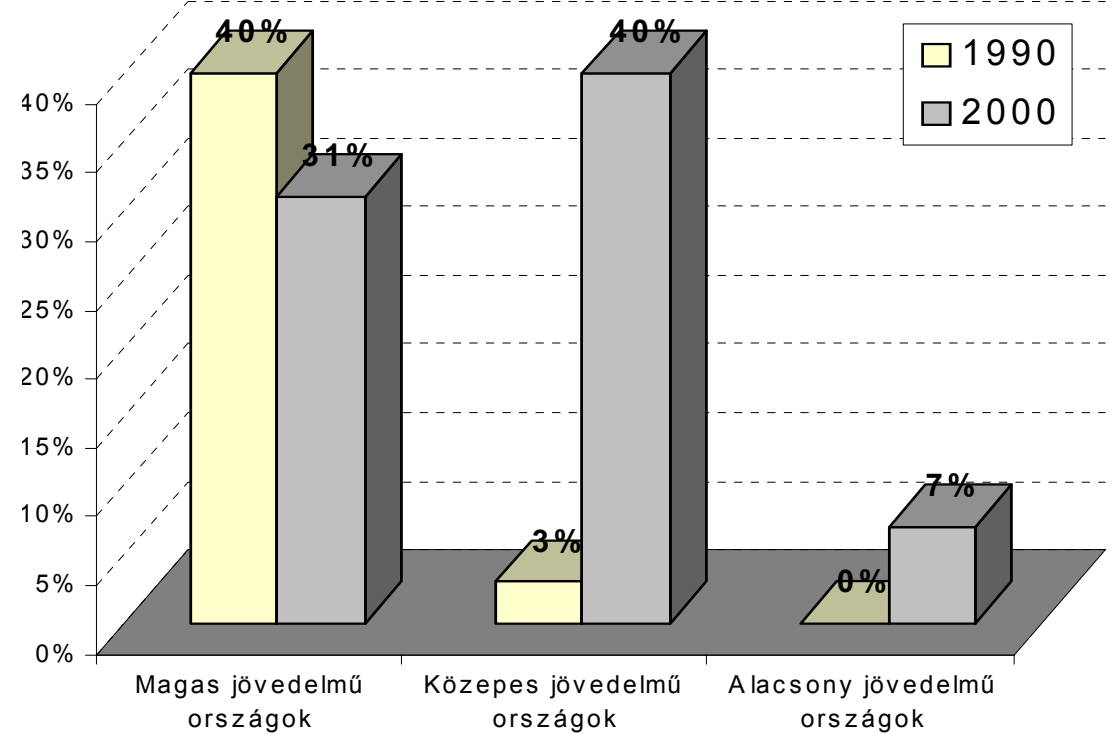

Forrás: (Claessens és társai 2006) 
Csehország, Magyarország, Lengyelország és Észtország esetében a nemzetközi porondon lévő vállalatok kapitalizációjának és a teljes piaci kapitalizációnak az aránya jelenleg kétharmad fölött van. Szlovákia és Litvánia követi őket közel egyharmados aránnyal. A forgalom viszonylatában hasonló következtetések vonhatók le. Lengyelországban és Észtországban például a piaci forgalom $60 \%$-a nem a hazai piacon bonyolódik. A hazai piac tőkepiaci kibocsátóinak száma is jellegzetes fordított „U” alakú mintát követ (ez alól Szlovákia képez kivételt).

Tehát a globális elvándorlás szükségszerűen bekövetkezik, fokozódó mértékben, mely egyre nagyobb nyomás alá helyezi a helyi tőzsdéket.

\section{Integrálódás, kapcsolatkeresés}

A fentiek tükrében a feltörekvő országok tőzsdéinek növekedési lehetősége igencsak korlátozott. Jelenlegi nagyságuk pedig világviszonylatban jelentéktelen (ld. 5. ábra).

\section{A globális részvénypiac struktúrája (2004)}

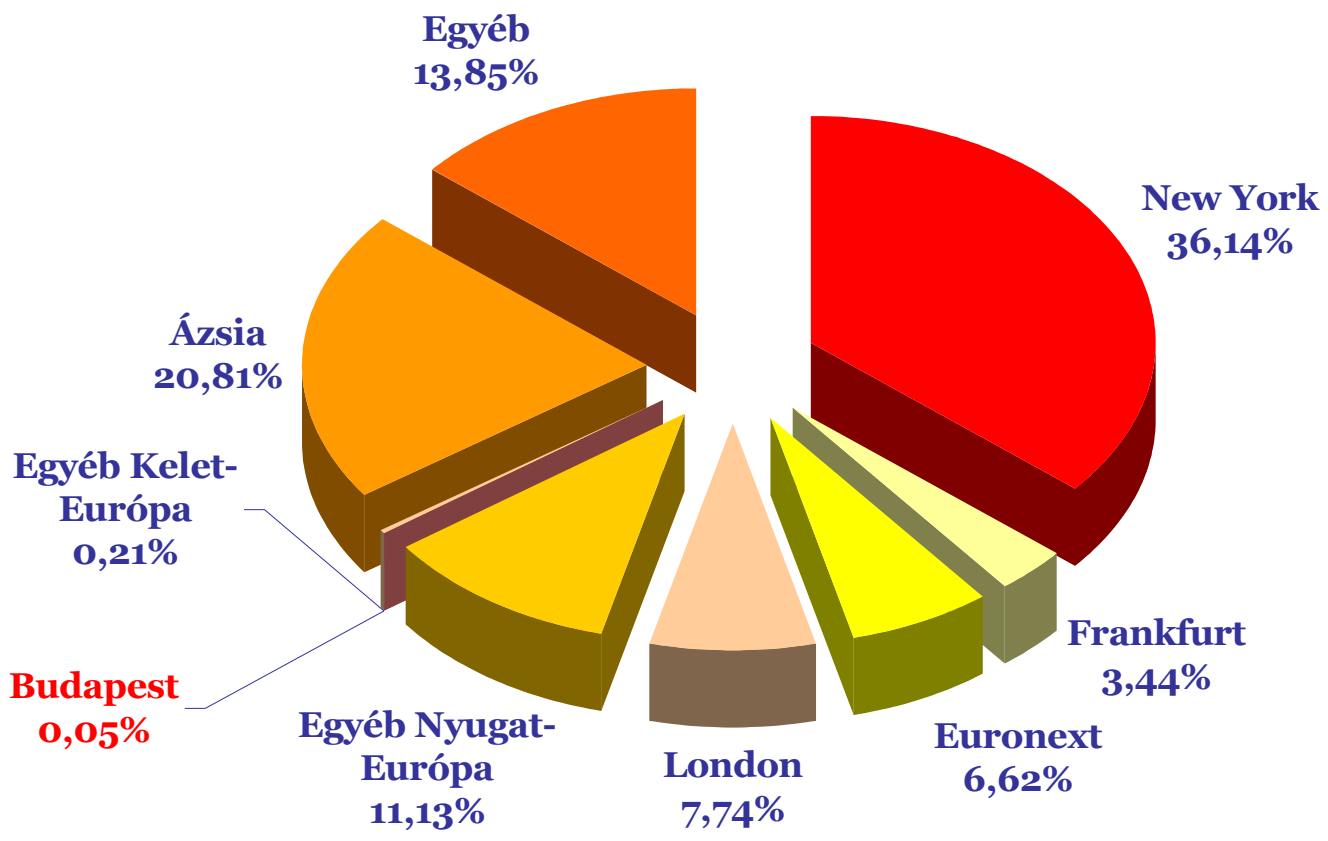

Forrás: (Horváth 2004)

Mi lehet akkor a jövő útja e piacok számára? Erre próbál választ keresni a következő alfejezet, a tőzsdék lehetséges alapvető stratégiáinak tárgyalásával.

A kilencvenes évektől Európában is megfigyelhetők voltak azok a kísérletek, melyekben különböző országok tőkepiaci szervezetei közeledtek egymás felé kapcsolatépítési szándékkal. Ez a konszolidációs folyamat, bár sajátos jegyeket hordoz, nem új jelenség. Az USA-ban az 1849-es aranyláz idején kezdődött meg a tőzsdék alapítása, majd 
a polgárháborút követően, 1865-re huszonegy börze müködött a tengerentúlon, sőt a huszadik század első éveire számuk meghaladta a kétszázat! 1934-ben a Glass-Steagalltörvények ${ }^{6}$ hatására már csak 49 maradt belőlük, míg napjainkra számuk fél tucatra csökkent (Clayton és szerzőtársai 1999).

Azt is látni kell ugyanakkor, hogy az ide vezető út sokkal kevésbé volt rögös egy országon belül, mint sok, különbözö jogrendszerrel, társadalmi-politikai hozzáállással és infrastruktúrával rendelkező ország esetében. Talán éppen ezért, e tendencia még csak körvonalazható, nem alakultak ki egyértelmű erővonalak az angolszász országokon kívüli tőkepiacokon. A legtöbb piac - a költségek csökkentésével és alternatív bevételi források felkutatásával - önerőből próbál továbblépni.

A feltörekvő országok tőzsdéi számára - a nemzetközi kapcsolatépítés intenzitásának függvényében - négy alapvető modellt különböztetek meg:

I. a. Izoláció, egyedi kiútkeresés a nemzetközi trendekkel szemben

b. Egyedi kiútkeresés, de a helyi piac elszámoló brókeren keresztül kapcsolódik valamelyik nemzetközi tőzsdehálózathoz

II. Laza regionális szövetség létrehozása, a környező országok tőzsdéi között

III. Egy vezető tőzsdével történő stratégiai szövetség kialakítása

IV. Teljes összeolvadás egy fejlett tőzsdével vagy tőzsdeszövetséggel (felvásárlás, egyesülés)

I. Ami az első lehetőséget illeti (a, b), a helyi tőzsdék elsorvadása - racionalizálással, konjunktúrapolitikával, a pillanatnyi helyzetnek megfelelő finomhangolással - csak elnyújtható, nem megállítható. Ez akkor sincs másképp, ha különböző technikákkal növelhető a piac likviditása. Ideiglenes megoldást jelenthet például a külső tagság (remote membership) megszervezése, ahol a külföldi befektetőket a hazai brókercégek kikapcsolásával engedik kereskedni a hazai börzén.

Leginkább a szűken vett Kelet-Közép-Európa országainak tőzsdéi követik ezt a kényszerű stratégiát. Egyelöre nem találnak nemzetközi partnert, egyedi kiutat keresnek, egyre nehezebbé váló körülmények között. Jellemző példája volt ennek például Magyarországon a Budapesti Értéktőzsde és a Budapesti Árutőzsde kapcsolatának szorosabbá tétele, mely jól mutatja a költséghatékonyság növelésének kényszerét.

II. Regionális szövetség kiépítésére speciális körülmények között van csak lehetőség. Szigorú feltételeknek kell teljesülniük ahhoz, hogy a szinergiahatásokat igazságosan osszák szét, és a résztvevők közül senki se törekedjen vezető szerepre.

Sikeresen működő regionális hálózat Európában a NOREX, mely a skandináv országok (Dánia, Svédország, Norvégia és Izland) tőzsdéinek kapcsolatrendszere. 1998 januárja óta a NOREX-en bonyolódik tagjai részvényforgalmának 80, kötvényforgalmának 90 százaléka. A harmonikus rendszert a következő szabályok alapozzák meg:

- közös tagság (minden résztvevő tagsága biztosított mind a négy ország piacán);

- egyedi kibocsátás (azaz duális kibocsátás nem engedélyezett egymás között);

- közös kereskedési rendszer (1999 óta az OM által kifejlesztett SAX 2000 rendszeren folyik a kereskedés a méretgazdaságosságot kihasználva); valamint

- a közös jogi szabályozás. 
Látható tehát, hogy a tőkepiaci intézményrendszer és infrastruktura igen magas foka szükséges egy regionális szövetség működtetéséhez.

1999 tavaszától regionális szövetség víziója körvonalazódott a balti országok esetében is. Észtország, Lettország és Litvánia tőzsdéi együttmüködési nyilatkozatot fogalmaztak meg a likviditás növelése, a balti piacok és közös kereskedési rendszer fejlesztése érdekében. 2001 augusztusában a Litván Tőzsde írt alá megállapodást a Varsói Tőzsdével (WSE) a szervezeti és technológiai szinergiák kihasználása érdekében. Tény, hogy a támogató egységek (marketing, sales, elszámolás, klíring, információszolgáltatás, egyéb adminisztráció, stb.) kompatibilissé tétele jó alap egy későbbi szorosabb együttmüködés megvalósulásához, jóllehet a balti államok piacait végül a NOREX integrálta.

Itt kell említést tenni a bécsi tőzsde helyzetéről is. Bécs - rendkívül alacsony forgalma miatt - korábban többször is megkörnyékezte a Budapesti Értéktőzsdét partnerségi vagy fúziós elképzeléseivel. A 2004-es év jelentett végül fordulópontot, amikor a magyar szabályozás lehetővé tette a $10 \%$ fölötti részesedésszerzést a BÉT-ben. Így az osztrák bankok és a bécsi tőzsde által alkotott konzorcium többségi tulajdonossá válhatott, mely egy regionális tőzsdeszövetség kialakítását vetítheti előre, bár konkrét, kézzel fogható eredmények egyelöre nem születtek.

III. Egy vezető értékpapírpiachoz történő csatlakozáskor a domináns szereplő adott, így nagyfokú alkalmazkodás és kompromisszumkészség szükséges az újonnan belépők számára. Különösen a menedzsment számára lehet nehéz az önállóság jelentős feladása. Mindezidáig kevés sikeres ilyen jellegű kapcsolat épült ki, bár próbálkozások voltak, például a Baltikum és a NOREX között. Ennek legfőbb oka, hogy előfeltétel az azonos makrogazdasági fejlettség és politikai-társadalmi tőkepiaci szemléletmód. Közel egyenrangú feleknél pedig a legtipikusabb probléma technológiai eredetü: melyik fél kereskedési rendszere optimálisabb a közös jövőben? Egy már működő megoldás adaptációja általában a gyorsabban járható út, de éppen egy tőzsdeszövetség komplex igényei miatt volna szükség egyedileg fejlesztett rendszerre. Hasonló jelentőségű az elszámolási rendszerek inkonzisztenciája, mely szintén akadályozott már meg integrációt.

Bécs és Frankfurt kapcsolata e változat specialitásának tekinthető. 1999 novemberétôl Bécs összekapcsolta kereskedési rendszerét a frankfurti tőzsde Xetra (Exchange Electronic Trading) rendszerével, ami lehetővé tette, hogy a bécsi tőzsde 80 résztvevője közvetlen kapcsolatba kerüljön Frankfurt mintegy háromszáz kereskedőjével, s az addig szinte zárt körben forgó részvények szélesebb európai környezetben mutassák meg magukat. Így az osztrákok gyakorlatilag a Xetra hálózatára kerültek, de nem azonos piacra. Az ő rendszerük jogilag független a Deutsche Börsétől. Tehát itt a tőzsde müködésének csak egy pontján alakítottak ki együttmüködést a felek.

A regionális helykeresés után a Baltikum piacai végül Helsinkivel léptek magasabb szintű szövetségre. 2001 februárjában a Tallini Tőzsde (TSE) és a HEX megkötötte stratégiai szövetségét. Helsinki 50\%-os részesedést szerzett az észt tőzsdében, és 2002 februárjában bevezette a kereskedési rendszerét. Áttekintve lehetőségeit a lett tőzsde is stratégiai partner keresésébe fogott, így 2002 augusztusában a HEX 92,98\%-os tulajdonrészt szerezhetett a rigai piacból. Mind a lett, mind az észt tőzsde függetlenül müködik, de az OMX márkaneve alatt ${ }^{7}$. A költségcsökkentés legfőbb tényezője a kereskedési rendszer 
adaptálása volt. 2004 májusában az OMX megszerezte a Vilniusi Tőzsde többségi részesedését is, így fogva össze az Észak-Baltikum összes szabványosított tőkepiacát.

2004 áprilisában az OMX piacai csatlakoztak a NOREX szövetséghez, majd 2004 szeptemberében áttértek a NOREX kereskedési platformjára, a SASSEX rendszerre ${ }^{8} .2005$ februárjában a Koppenhágai Értéktőzsde (CSE) is csatlakozott az OMX-hez.

Varsó az Euronext felé nyitott, 2001-ben bevezette annak kereskedési rendszerét.

IV. A teljes integráció azt jelenti, hogy feltétel nélkül minden elemében beolvad a csatlakozó tőkepiac egy másik hálózatba. A kezdeti nehézségektől eltekintve hosszú távon így érhető el a maximális költséghatékonyság:

1. Az összes előny egy szervezetnél realizálódik, azaz nem keletkezik súrlódás a szinergiaallokációból, mint ahogyan az lazább kapcsolódásokban történik.

2. A piac vonzási képessége a méretből és a szoros kapcsolatból adódóan hitelesebb.

3. Az egyesült szervezet belső koherenciája magától is összecsiszolja az együttműködő feleket, nem kell azt elöre külső biztosítékokkal megoldani ahogyan lazább kapcsolatépítés esetén.

A tőzsdék szervezete számára így létrejövő előnyök mellett azt is látni kell, hogy ebben az esetben a piac méretéből adódóan ismét csak megnő a kereskedett vállalatok optimális mérete, vagyis a helyi vállalatok egy köre számára elveszik az információs hatékonyság.

Előnyei ellenére kevés egymásra találásnak lehettünk tanúi a múltban, hiszen még ott is sok tárgyalás fulladt kudarcba, ahol a közös szándék megvolt. A nemzeti identitás eltünésének sokszor politikai vetületei is vannak. További probléma, hogy az elönyök hosszú távon jelentkeznek, de a szervezetek illeszkedésének kezdeti költségeit egyik fél sem vállalja.

Sikeres példája a fúziós megoldásnak az Euronext esete. Az Euronext 2000-ben jött létre a korábbi francia (Société des Bourses Françaises SA, SBF), holland (Amsterdam Exchanges NV, AEX) és belga (Société de la Bourse de Valeurs Mobilières de Bruxelles SA/Effectenbeursvennootschap van Brussel NV, BXS) tőzsdék egyesülésével. Mindhárom börze az Euronext NV leányvállalata lett ${ }^{9}$, új nevük: Euronext Paris, Euronext Amsterdam és Euronext Brüsszel. A vállalatok papírjait közös platformon forgalmazzák, így mind kibocsátói, mind kereskedési szempontból az optimális megoldást élvezik. E megoldás sikerét mutatja, hogy az Euronext indulása óta eltelt néhány évben felvásárolták a Londoni Nemzetközi Határidős Tőzsdét, a LIFFE-t (2002. december) ${ }^{10}$, és a portugál értéktőzsde (Lisbon Stock Exchange) is csatlakozott az egyesüléshez. Az Euronext példája azért kivételes, mert a résztvevők képesek voltak megtartani identitásuk főbb elemeit.

2005 májusában hirdették ki az egyesült balti piacok koncepcióját, melyben teljes integráció jött létre a NOREX Group alatt a három balti ország tőzsdéi között (közös értékpapír-kibocsátás, közös kereskedési szabályok, valamint közös tagság és elszámoló és letéti rendszer).

Úgy tünik tehát, hogy egy feltörekvő tőkepiac számára elkerülhetetlen az önállóság (legalább részleges) feladása és kapcsolódása egy érett, életképes pénzügyi központhoz.

${ }^{8}$ Vilnius csak 2005 májusában adaptálta ezt.

${ }^{9}$ A tulajdoni arány a fenti tőzsdék tulajdonosai között rendre 60\%, 32\%, 8\%.

${ }^{10}$ Azóta az Euronext származékos tevékenységének döntó része a LIFFE elektronikus kereskedési platformján, a Connecten zajlik. 
De vajon melyik út az optimális? Véleményem szerint egy közös, regionális tőzsde csatlakozása egy nyugati piachoz járhatna a legkedvezőbb hatásokkal:

- A jobb alkupozíció miatt a korábbi menedzsment befolyásának fennmaradása (kompromisszumokkal).

- A lehető legnagyobb nyilvánosság és átláthatóság a forgalmazott vállalatok számára.

- Teljes harmonizáció jogi szempontból, és a költségszerkezet tekintetében (az EU direktívának megfelelően).

- Az egyes nemzeti érdekek és kormányok befolyása és torzító intézkedései alól való kikerülés.

- A fentiekből következően ez a legvonzóbb megoldás a külföldi befektetők számára is, mely pozitív kört indítva növekvő likviditással és kibocsátási kedvvel párosulna.

Második legjobb megoldásnak az egyedileg történő integrációt látom. Ekkor ugyanis a korábbi menedzsment nagyrészt feladja pozícióit és tacit tudását, kisebb a kényszer a harmonizációra. Az integrálódó kisebb piac elsorvadhat, és kibocsátói kevésbé lesznek láthatóak, vonzóak a nemzetközi befektetők számára, bár még mindig jobban, mint egyedileg, integráció nélkül.

Térségünk piacai számára lehetséges partner lehet a Deutsche Börse, a Euronext, a LSE és a Norex. A Deutsche Börse és London a legkevésbé valószínű aktív partner. Mindkét fél - mint a legnagyobb piacok Európában - azt igyekszik elérni, hogy a fejlődő országok vállalatai közül a legjelentősebbek és így a legnagyobb forgalmat bonyolítók, náluk külön jelentkezzenek kibocsátóként.

Mi jelenthet esélyt a csatlakozáshoz a feltörekvő tőkepiacok számára? A 7. ábrán is látható módon egyelöre rendkívül polarizált az európai tőzsdék kapcsolati rendszere. Az integrálódási folyamat azonban olyannyira akadozó, hogy lehetőséget nyújt az újak számára a felzárkózáshoz.

Összeurópai szinten azonban, az amerikai és japán piacokkal való versenyben nyilvánvalóan kívánatos a legnagyobbak integrációja. A közös európai piac létrejötte már az 1990-es évek elején konkrét elképzelésekben öltött testet, amikor a legnagyobb hat piac összeolvadásának terve meg is született. A kereskedési és elszámolási rendszerek öszszeegyeztetése azonban túl nagy feladatnak bizonyult. Bár folyamatosan merülnek fel az újabb és újabb egyesülési ötletek, kísérletek ${ }^{11}$, még a kereskedési idők harmonizációja sem valósult meg mindmáig. A közeljövőben pedig a fent bemutatott regionális kapcsolatépítések sem fogják megkönnyíteni az összeurópai tőkepiac kialakulását.

111998 júniusában kezdődött az első iX-projekt, ahol a London Stock Exchange (LSE) és a Deutche Börse (DB) közös stratégiai szövetség kialakítását célozták meg. Az első körben egységes kereskedési rendszert terveztek, majd ettöl - magas költségei miatt - visszaléptek. A tervek szerint 2000 novemberében indult volna a közös müködés, de szinergiahatások hiányában és a tradicionális különbségek miatt a végső megállapodás kútba esett. 2002 első felében felmerült az a lehetőség is, hogy a Nasdaq és az LSE egyesülésével létrejöhet a világ legnagyobb koncentrált tökepiaca. A németek ( $a$ Deutsche Börse AG) erre válaszul ismét vételi ajánlatot tettek a LSE-re. Végül egyik elképzelés sem valósult meg. 2005-ben a német fél még egy alkalommal megpróbálta felvásárolni a LSE-t, de a kisrészvényesek meggyőzése ismét sikertelennek bizonyult. Az LSE részvényeinek megszerzéséért az OM-csoport is jelentkezett, sikertelenül.

Az amerikaiak válaszlépése az volt, hogy a Nasdaq 2001. március elején többségi tulajdont szerzett az Easdaqban, amelynek a neve Nasdaq Europe lett. A Nasdaq a LIFFE-vel, a londoni származékos piaccal is kapcsolatba került, amikor megállapodást kötöttek, arról, hogy a New Yorkban kereskedett határidős kontraktusokkal akkor is lehet Európában üzletelni, amikor a tengerentúlon a piacok zárva tartanak. 
6. ábra

\section{Az európai tőzsdék kapcsolatrendszere}

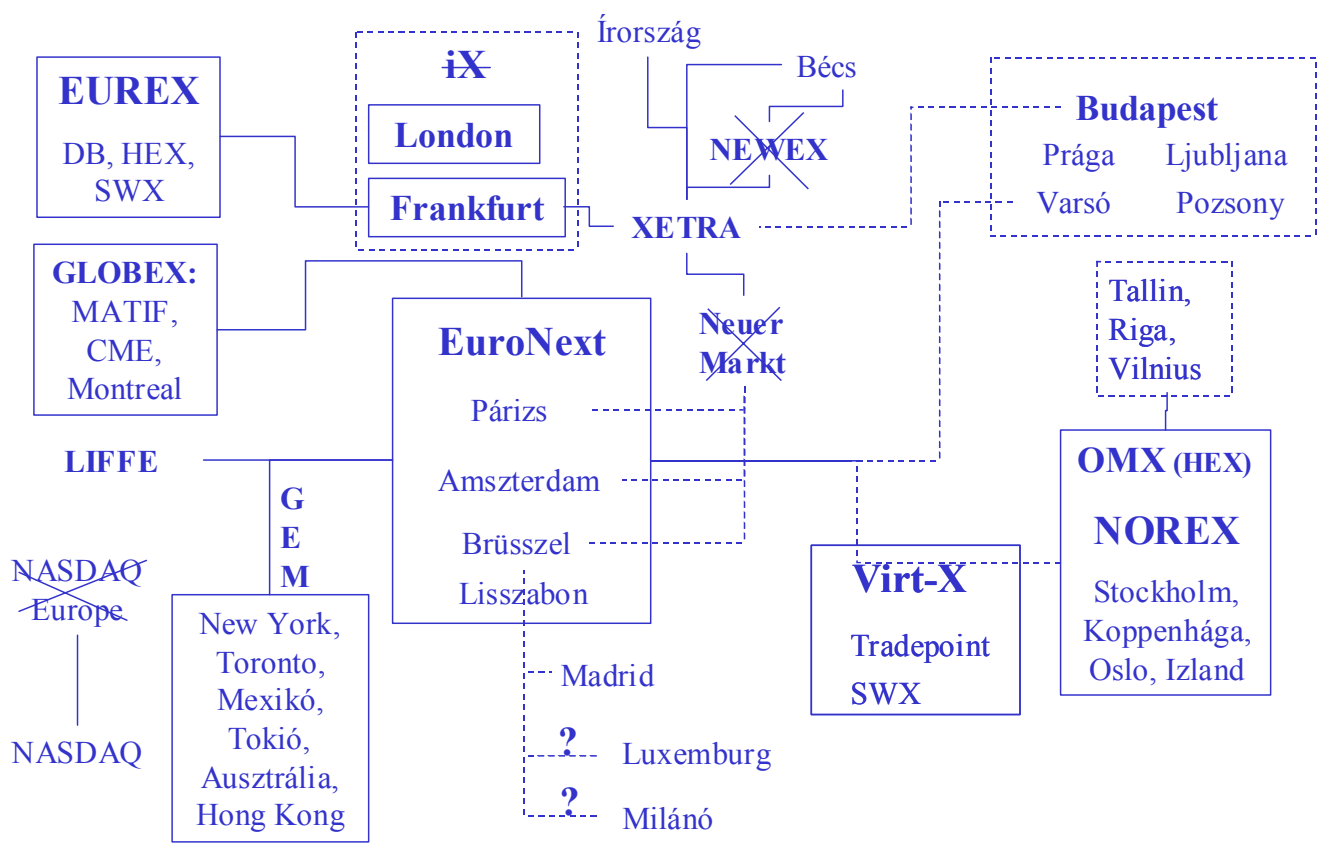

Forrás: (Horváth 2001), saját kiegészítésekkel

\section{Következtetések}

Fontos hangsúlyozni azt, hogy a feltörekvő tőkepiacok fejlődésének egy adott szakaszában fellendülésük és hanyatlásuk azonos forrásból származik. Éppen a makrogazdasági fundamentumok javulása, az átláthatóság és a hatékonyságnövekedés vezet oda, hogy a vállalatok egyre nagyobb köre képes megfelelni a nagy és hatékony tőkepiacok elvárásainak, mind likviditás, mind volumen tekintetében. A külföldön való megjelenés a fejlödés párhuzamos velejárója, és abból adódik, hogy, bár a tőkepiac adott területeken fejlődőképes, és látszólag lépést tart a fejlett tőkepiacokkal, valójában a belső pénzügyi közvetítés funkcionálisan nem versenyképes. A migráció következtében a vállalatok tőkevonzó képessége növekszik, miközben olcsóbban, rövidebb határidővel, nagyobb befektetői körben tudják teríteni papírjait. A befektetők számára pedig még nagyobb likviditást, és így alacsonyabb implicit költségeket jelent a nagyobb piac. A külföldi kibocsátás negatív hatása a hazai tőkepiacra annak természetes marginalizációját okozza. Ennek mértékét és ütemét lehet késleltetni, hosszú távon pozitív és negatív hatásokkal. Negatív mechanizmusokat indukál, ha a tőke szabad áramlását, illetve a hazai pénzügyi közvetítők portfolióját jogi eszközökkel, adminisztratív korlátozásokkal befolyásolják, ahogy erre - az elmúlt másfél évtized tapasztalata alapján - számos példa hozhatón ${ }^{12}$. Pozitív folyamat,

12 Lengyelországban például még az 1990-es évek végén is egy nyugdíjalap portfoliójának legalább 95\%-t belföldön kellett befektetnie, így a kockázatcsökkentés természetes módja (diverzifikáció) helyett más megoldást kellett találnia a kockázat csökkentésére, mely szuboptimális eszközallokációhoz vezetett. 
ha a tőzsdék költségeinek racionalizálásával, nemzetközi stratégiai partner keresésével, és a befektetői szemlélet hosszú távú átalakításával képesek a kibocsátók minél szélesebb körére támaszkodva müködni. A fentiek együttes teljesülése esetén a hosszú távú hanyatlás elkerülhető. Ehhez azonban szerkezetátalakuláson, transzformációs folyamaton kell átesnie a tőkepiacnak.

A strukturális átalakulás, a visszaesés hossza a következők függvénye:

- A makrogazdasági stabilitás fenntarthatósága és a külföldi tőke megnyerése a kisebb, de tőzsdeképes vállalatok számára.

- A társadalom piackonform magatartása és a piaci szemlélet kialakulásának foka (a belső megtakarítások képesek-e részben átvenni a külföldi tőke szerepét, amikor azok intenzitása a nagyvállalatok migrációját követően visszaesik).

- Képes-e a bankrendszer egyedül megteremteni a hatékony forrásallokációt? Azaz, kialakul-e a pénzügyi közvetítőrendszer evolúciójának első szakaszát jellemző stabil architektúra?

Vessünk egy pillantást a tőzsdei kapitalizáció GDP-hez mért arányára, és ennek alakulására a vizsgált országokban. Ez egyben gyakran alkalmazott mértéke a pénzügyi közvetítés mélységének a tőkepiac oldaláról, mely az EU-15 országaiban, de Máltán és Cipruson is $120 \%$ fölött van. Látható, hogy az elemzett nyolc ország közül, 2004-ben a listavezető Észtország sem érte még el az 50\%-os szintet sem (7. ábra).

\section{Tőzsdei kapitalizáció/GDP}

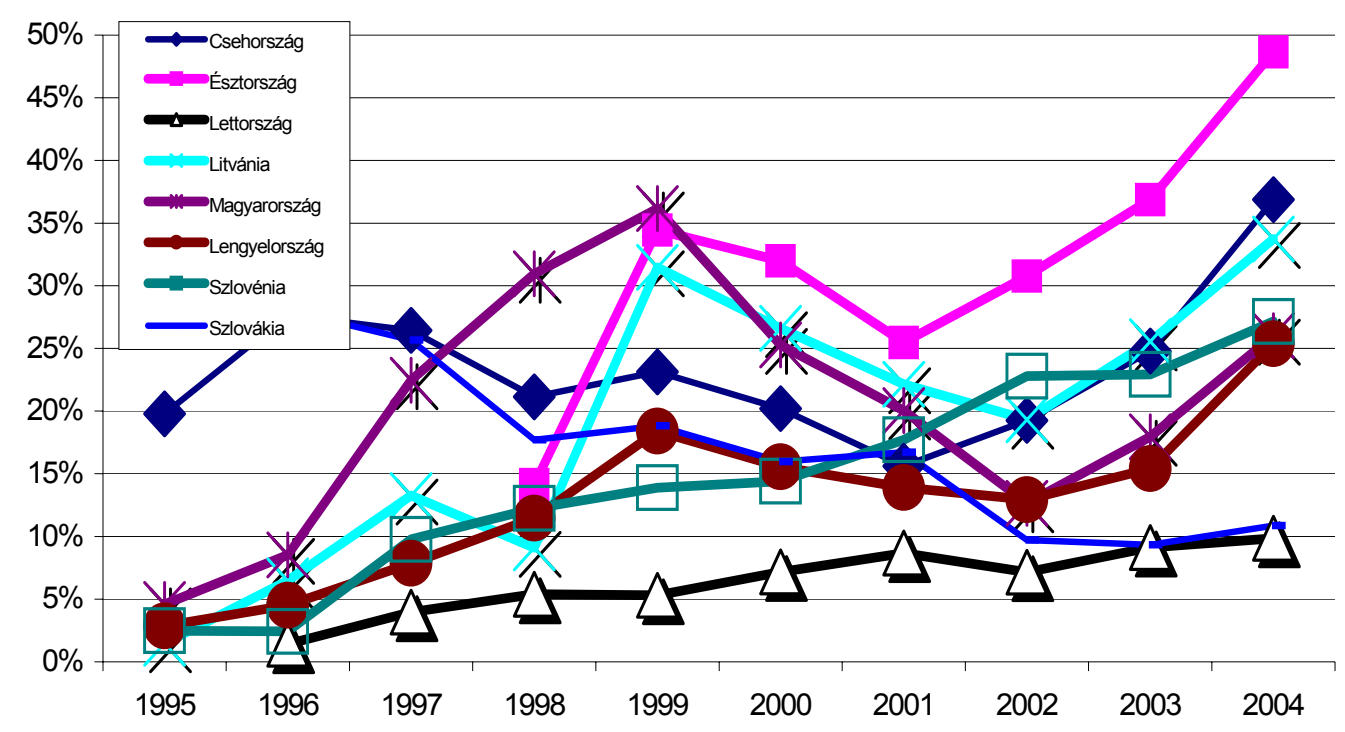

Forrás: (Eurostat 2005)

Bár az adatok is alátámasztják az átalakulás elméletét, vagyis szinte minden országban bekövetkezett a kapitalizáció visszaesése, majd ismételt növekedése, ez koránt sem jelenti, hogy a szerkezeti transzformáció lezajlott. Egy ország tőkepiacát addig semmiképpen sem tekinthetjük érettnek, ameddig nem esett át a megfelelő átalakuláson, függetlenül 
attól, hogy likviditásban és kapitalizációban mennyire közelíti meg a fejlett országok hasonló mutatóit. A tőzsdék funkcionális hatékonyságának további vizsgálata, egyéb mértékeinek elemzése, így például a szinkronitásvizsgálat egy következő tanulmányom témája lesz.

\section{Hivatkozások}

Akyüz, Yilmaz - Cornford, Andrew (2002): Capital Flows to Developing Countries and The Reform of the International Financial System. In: Nayyar, D. (szerk.) Governing Globalization. Oxford University Press, Oxford - New York, 108-143.

Bae, Kee-Hong - Stulz, René M. - Tan, Hongping (2005): Do Local Analysts Know More? A Cross-Country Study of the Performance of Local Analysts and Foreign Analysts. National Bureau of Economic Research Working Paper, 11697. sz., Cambridge, MA.

Claessens, Stijn - Klingebiel, Daniela - Schmukler, Sergio L. (2002a): FDI and Stock Market Development: Complements or Substitutes? Elhangzott a „The FDI Race: Who Gets The Prize? Is It Worth The Effort?"konferencián. Washington, D.C., 2002. október 3-4., World Bank, Washington.

Claessens, Stijn - Lee, Ruben - Zechner, Josef (2003a): The Future of Stock Exchanges in European Union Accession Countries. Corporation of London, Centre of Economic Policy Research. http://www. cityoflondon.gov.uk/business_city/research_statistics/pdf/Future_SEs_EUAC.pdf. Letöltve: 2003. október 7.

Claessens, Stijn - Klingebiel, Daniela - Schmukler, Sergio L. (2003b): Accessing International Equity Markets: What Firms from Which Countries Go Abroad? Working Paper University of Amsterdam and World Bank. http://icf.som.yale.edu/pdf/seminars04-05/Claessens.pdf. Letöltve: 2003. október 7.

Claessens, Stijn - Klingebiel, Daniela - Schmukler, Sergio L. (2006): Stock Market Development and Internationalization: Do Economic Fundamentals Spur Both Similarly? Journal of Empirical Finance, (megjelenés alatt).

Clayton, Matthew J. - Jorgensen, Bjorn N. - Kavajecz, Kenneth A. (1999): On the Formation and Structure of International Exchanges. Nem publikált műhelytanulmány. New York University, Stern School of Business, 1999. szeptember.

Davis, E. Philip (1995): Pension Funds, Retirement Income Security and Capital Markets - An International Perspective. Oxford University Press, New York.

Doidge, Craig - Karolyi, G. Andrew - Stulz, René M. (2004): Why Are Foreign Firms Listed in the U.S. Worth More? Journal of Financial Economics, 71. évf., 2. sz., 205-239.

Eurostat (2005): Eurostat on-line adatbázis. http://epp.eurostat.cec.eu.int. Letöltve: 2005. október 18.

Horváth Zsolt (2001): A Budapesti Értéktözsde (előadás). Budapesti Közgazdaságtudományi és Államigazgatási Egyetem, Budapest, 2001. november 19.

Horváth Zsolt (2004): A Budapesti Értéktőzsde Részvénytársaság, Célok, stratégiák, eredmények. Előadás, Gyöngyös, 2004. május 6.

Levine, Ross - Schmukler, Sergio L. (2003): Migration, Spillovers, and Trade Diversion: The Impact of Internationalization on Stock Market Liquidity. Policy Research Working Paper, 3046. sz., The World Bank; National Bureau of Economic Research Working Paper, 9614. sz., Cambridge, MA.

Levine, Ross - Schmukler, Sergio L. (2005): Internationalization and Stock Market Liquidity. Mühelytanulmány, IMF Research Department, 2005. december.

UNECE Economic Survey (2005): Statistical Database - United Nations Economic Commission for Europe. http://w3.unece.org. Letöltve: 2005. október 22. 